\title{
International Society of Endocriology
}

\section{VIПth International Congress of Endocrinology}

Kyoto, Japan, July 17-24, 1988

For further information, write to the Secretariat: Dr. H. Imura, Department of Internal Medicine, Kyoto University Faculty of Medicine, 54 Shogoin Kawaharacho, Sakyo-ku, Kyoto 606, Japan

The Executive Committee of the International Society of Endocrinology met this summer to elect a chairman and members of the Program-Organizing Committee (POC). Since the scientific success of the Congress depends on this Committee, the members and alternates are elected on the basis of their current areas of interest, scientific reputation, international recognition, geographical representation, and ability to work constructively in building a scientific program. This Executive Committee, as the previous one, decided that previous members of the POC would not be eligible for election and that POC members could not be Plenary or Symposium lecturers.

I am pleased to report that all of the electees agreed to participate. The membership of the POC follows. Dr. Halasz or the Secretary General would be pleased to hear from any member of the ISE about any matters concerning the program: Dr. B. Halasz, Histology and Embryology, 2nd Department of Anatomy, Semmelweis University Medical School, Tusolto utca 58, 1094 Budapest IX (Hungary).

Dr. Gerald D. Aurbach, USA

Dr. C. Wayne Bardin, USA

Dr. Lutz Birnbaumer, USA

Dr. Stephen R. Bloom, UK

Dr. Brian K. Follett, UK

Dr. Pierre Freychet, France

Dr. John W. Funder, Australia

Dr. William F. Ganong, USA

Dr. Minoru Irie, Japan

Dr. Vivian H.T. James, UK

Dr. Selna L. Kaplan, USA

Dr. Kenneth P. McNatty, New Zealand

Dr. N.R. Moudgal, India

Dr. P. Seeburg, FRG

Dr. Mario Serio, Italy

Dr. Wylie W. Vale, USA

Dr. Bernardo L. Wajchenberg, Brazil

Dr. K. von Werder, FRG

Dr. Leif Wide, Sweden 
Application for Travel Awards to the VIHth International Congress of Endocrinology

The Awards Committee of the ISE is prepared to make travel grants for the VİHth International Congress of Endocrinology. The Committee will screen and rank the applicants. The awards will be $80 \%$ of the Apex fare from your home airport to Kyoto. Application forms may be obtained from the Secretary-General, ISE, 51-53 Bartholomew Close, London, EC1A 7BE, UK.

Awards will be made by the Awards Committee. Preference will be given to young endocrinologists and/or to endocrinologists from Third World countries who have demonstrated interest in endocrine research. These awards are intended for individuals who have no other source of funds to attend the Congress.

The deadline for receipt of completed applications is February 1st, 1988. Notification of awards will be made in March, 1988.

\section{0th Annual Meeting of the Society for the Study of Reproduction}

Urbana, Ill., July 20-23, 198

The program of this meeting, which will be held at the University of Illinois in Urbana, will include a Symposium on Embryo-Maternal Relationships, three 'state of the art' lectures on NMR imaging and spectroscopy, and an awards ceremony, as well as sessions devoted to research papers. To obtain additional information about the program or submission of contributed papers, please contact: Executive Secretary, The Society for the Study of Reproduction, 309 West Clark Street, Champaign, IL 61820 (USA) 